\title{
Religious Minorities in Iran
}

Eliz Sansarian, Cambridge: Cambridge University Press, Cambridge Middle East Series, n.d., 228 pp.

The author is an associate professer of political science at the University of Southem Califomia. Her previous publications include a 1982 Praeger publication, "The Women's Rights Movement in Iran: Mutiny, Appeasement, and Repression from 1900 to Klhomeini."

Religious Minorities in Iran is of interest to political scientists, particularly those focused on the Middle East; Iran experts; Islamic studies experts concerned with modern-day politics and governance; those in the field of religious studies or comparative religion; and also lawyers, academics, and those working in Non-Governmental Organizations (NGOs) in the human rights field who are interested in issues related to minority rights, freedom of religion or belief. and human rights in the Middle East.

The book focuses on those identified as the main ethnoreligious components of the non-Muslim religiøus communities in Iran: Armenians, Assyrians, Chaldeans, Jews, Zorastrians, Bahá'is, and Iranian Christian converts. The main period of study is the first decade of the Islamic Revolution of Iran, 1979 to 1989. The auther gives three reasons for focusing on this period; she argues that this was the most ideologically charged moment of the revolution, that the position of recognized non-Muslim minorities was largely routinized by the late 1980)s, and because she wants to avoid the nuances that emerge and complicate the political scene after the end of the cold war and the formation of post-Soviet states. Later periods are mainly considered only when they bear direct relevance to the points being made and in the concluding chapter. 
In the preface the author poses two questions: What has been the overall policy of the theocratic Islamic state toward its non-Muslim religious minorities? and How have the minorities dealt with state intrusion into their lives? The dynamic relationship between these two questions becomes evident as they are pursued in the length of this study, through a consideration of sociopolitical, historical, psychological, theological and legal factors. The study is rich in the range of methodological tools it utilizes in the examination of this complex subject.

The introductory chapter, "An Overview of Politics and Society," provides the conceptual framework of the study. It contains a brief overview of twentieth century Iranian politics, surveys the role of non-Muslims in Islam, and allows the reader to perceive non-Muslims through the eyes of the "Shi'i revolutionary ideologues." It also explores the definitions of terms such as "ethnic group,' 'ethnicity,' 'minority,' and 'state.'

The author dismisses the Pahlavi rulers' policy on ethnonationals and religious minorities as aiming toward their homogenization and, surprisingly perhaps, claims that the Islamic Revolution's approach differed in that it had a "cognizance of ethnic and religious diversity and acceptance of the permanence of the pluralistic nature of society" (p. 6). The author adds, however, that "acceptance does not preclude the use or the threat of use of coercion" (p. 6).

In the introduction the author makes the sharp distinction between the recognized religious minorities (Armenians, Assyrians, Jews, and Zoroastrians) and the excluded groups (the Bahá'ís and Muslim converts to Christianity), with state elites being "unanimously and venomously dismissive of both of the latter groups, targeting them for violence and persecution" (p. 6). This sharp demarcation is carried on throughout the study.

Chapter 1, "Ethnic Anatomy and Politics of Non-Muslim Minorities," notes the unevenness and the complexity and dearth of research on Iran's religious minorities. Sansarian explores the situation of Iran's religious minorities before the outbreak of the Islamic Revolution in 1979. The chapter introduces each religious community and examines its overall relations with Iranian society and the state. It then identifies several patterns in state-minority relations relating to the Armenians, Assyrians and Chaldeans, Jews, Zoroastrians and Bahá'ís. She summarizes these patterns as:

- "Differential legitimacy zones": i.e., differing relations with Shi'a authorities, here examining the pre-1979 context;

- "Perpetual clerical bigotry";

- "Nationalist xenophobia": from the 1930s to the 1970s; 
- "Two faces of the era of the shahs": homogenization of Iranian religious minorities alongside their overall lack of visibility.

Chapter 2, "The Assembly of Experts: Debut in the Year of Destiny," reflects on the ideological impetus and direction of the revolution through a painstaking analysis of the role of the four non-Muslim deputies (Armenian, Assyrian, Jewish, and Zoroastrian) in the process of shaping the Iranian Constitution. This is done by looking at the discussions held by the Assembly of Experts (Majlis-e Khebregan) in 1979.

This chapter is perhaps the most fascinating part of the book due to its examination of the rather unique contribution of a chosen few non-Muslims in the shaping of a modern Islamic state. The study reflects the sensitive political dynamics at stake on both sides and reveals the parameters in which they were able to operate. Sansarian is able to reveal the purposeful anti-Bahá'í considerations during these deliberations, and the delicate distinction made between strong anti-Zionist sentiment alongside the acceptance of Iranian Jewish representation at the discussions.

Chapter 3, "Policy Sphere of Recognized Religious Minorities," moves on to examining state policies relating to recognized Iranian religious minorities (i.e., Armenians, Assyrians and Chaldeans, Jews, and Zoroastrians). Sansarian brings out the differing political measures of acceptability by exploring policies within the following spheres of recognized religious minority operation: religion, education, communal life, and political representation. In each of these spheres, she examines the gap between the legal assertion of protection versus the political realities as experienced by the recognized minorities. Overall, she outlines the continuity of religious minority policies from the Pahlavi period. But she also emphasizes that, in reality, life became more "taxing and complex" (p. 73) for these minorities, due to the coexistence of both their legal protection and their subjugation.

Chapter 4, "Distinctions and Designations as Policy Output," examines the state policies toward excluded religious minorities. Sansarian adopts a psychological framework to explore the severity of treatment meted out to Jews (although a recognized minority), the persecution of Bahá'ís, and the situation of nonethnic Christian groups (i.e., Iranian converts to Christianity). She seeks to understand the policies toward these three groups by exploring the stereotypes underlying their treatment. She partly attributes the regime's motives to its "intense preoccupation" (p. 129) with, and "increasing fixation" (p. 129) on, the possibility of Muslims converting to other religions, while it was allowing ample opportunity for publicizing the conversion of non-Muslims to Islam. 
The final chapter, Chapter 5, "Prevalent Responses of Recognized Religious Minorities, explores both the common and differing responses of the recognized religious minorities to both local governments and state policies. Sansarian identifies the common practice among some of the groups of bartering public shows of obedience for continued protection by the state, and how this was in fact indicative of the perilous situation for these minorities. Some unique responses from each of these minorities are also explored, thus indicating among them different levels of confidence, changing circumstances, and varying shades of conformity.

In conclusion, Sansarian reflects on the "perils of marginality." He revisits the term 'otherness' and the marginality contained in the term 'minority.' At best, Sansarian concludes that this led to the compartmentalization of the religious groups. Excluded groups suffered in line with the stereotypes assigned to them according to their level of westernization and the perceived threat they represented. She attributes the harshness of treatment toward these groups to the political goal of exerting social control on the Shi'a polity. The author then reflects on the post-1989 situation of these religious communities and their continued marginalization. Finally, Sansarian ends her study with a challenge and with the hope that fundamental lessons be learned from this experience. She does not recommend a particular model or plan of action to be pursued in this regard, but her overall sentiments are clear.

This monograph provides a detailed study on a matter which has received little attention in academic work to date. It gives an interesting analysis of an area on which it is clearly difficult to get information. In fact, the book is rich in the detail of its research and in the anecdotes brought out by the author's fieldwork.

The study gives a brave and balanced examination of a field in which polarisation of views is commonplace. It utilizes a variety of primary sources, including personal interviews, published interviews, documents obtained during field trips to Iran, theological writings from relevant religious leaders, goverrimental records such as the proceedings of the Assembly of Experts and the Majlis (parliament), as well as references to periodicals from religious minorities. It also gives an interesting analysis of the interaction of the political, legal and social contexts, and their impact on religious minorities.

While the reader may not expect more detailed attention to the pre-1979 history of religious minorities than what the author provides, the choice of focusing primarily on the period up to 1989 is a little frustrating, as it begs the question of what changes may have accrued to Iran's religious minorities since that time. But the author has provided strong reasons for the 1979-1989 timeframe, and the fluctuations of more recent times may also benefit from a measure of hindsight for their final analysis. 
The lack of attention this publication gives to examining the situation of the Sunni population of Iran, which has been estimated at about 10 percent of the total population, is also a little surprising. But since Sansarian utilizes the Iranian government's political, and particularly constitutional, framework for the categories she explores, this does explain the omission. Since Sunnis have always been presented as cobelievers by Iranian ideologues, there has been a strong resistance to any separate provision or consideration for them. This, however, has not meant that they have escaped discrimination in the political turbulence of the times being examined in this study.

The reader will need other publications to examine the international response to the situation of Iran's religious minorities, to explore the issue of Iran's religious minorities using the prism of human rights, and to relate human rights to Iran's international standing and foreign policy. Studies which compare and contrast the situation of religious minorities in Iran with neighboring states and other Muslim states will also be of much interest. This subject could also benefit from further a more detailed examination of divergences among different governmental actors in Iran, the standing and role of different ministries in Iran in this process, the ideological impact of the various political forces in the country and its effect on the treatment of religious minorities, and the gap between legislation and political action.

This book does not explore "Islamic thought" as such, although it clearly has implications for it. Its primary attention is on the interpretation and application of Islam as the basis for political ideology in the context of revolutionary Iran. It would certainly be interesting to review this case study, and the political ideology of the first decade of the Islamic Republic of Iran on which it rests, in the light of contemporary Islamic thought. A historical analysis of the status of non-Muslims under Islamic rule from the Makkan and Madinan periods, stretching to the millet system, and the situation in other modern-day Muslim states, would be one way forward. An analysis of the application of the Shariah to non-Muslims in other contexts today, and their position in relation to criminal, inheritance, and other laws, would be another way of basing this analysis in a much broader context. The case study itself, however, provides a unique analysis of the experience of religious minorities in one place at one period of time.

Dr. Nazila Ghanea-Hercock M.A. Convenor and Lecturer in International Law, ICS University of London United Kingdom 